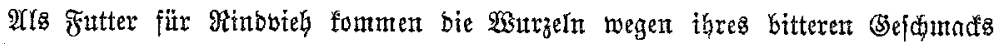
nidit in Betradit.

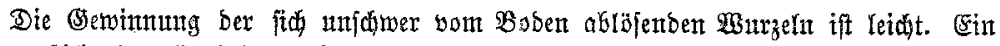

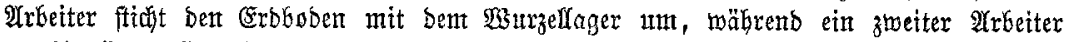

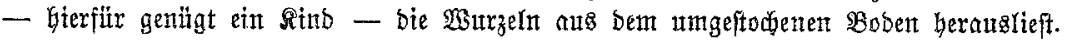

Die Margern mitfen gewonnen werben, ehe bie jungen bebel int

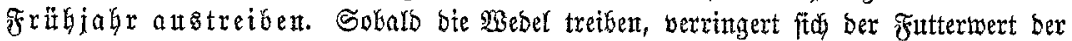
Sasurzelt erbeblito.

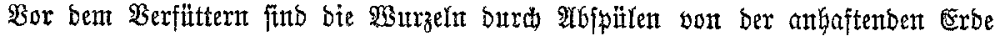
zll befreten. Einer weitgehenten Berfleinerung vber fonftigen Bubereitung bebïrfen fie

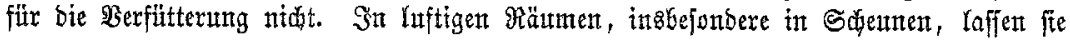
fitif gut aufbewatiren.

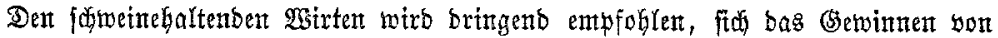

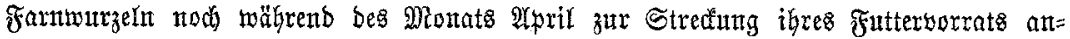
gelegen jetn zu laffent.

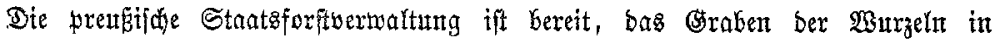

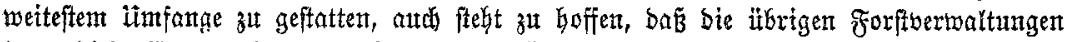
bas gleide Crntgegentommen zeigen werber."

\title{
forffltcher $\mathfrak{U}$ ntertidgt.
}

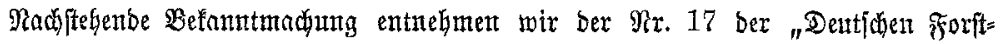
zeitung" ;

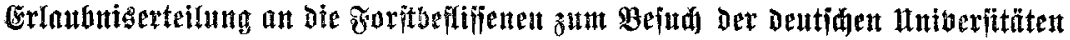

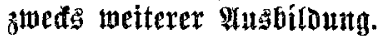

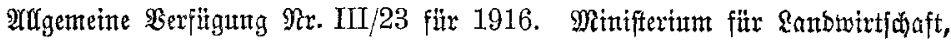
Domänen uth Forften. $\Im . .9 x$. III 2204.

Berlit W 9, 7. Ypril 1916.

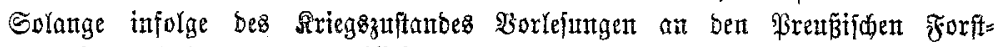

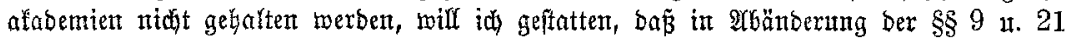
Der Beftimnungen $\ddot{u} 6 e r$ bie Borberettung für ben Röntglicher Forfterwaltungsbienft yom 19. Februar 1908

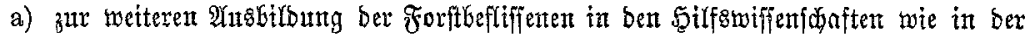

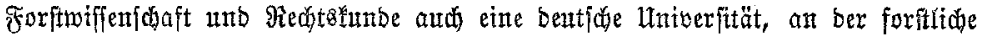
Borlejungen gebalten werben, bejudt werben barf, jebod läthftens 2 Semefter,

b) zu bem in $\$ 21$ borgefdriebenem Stutbium ves Staatzredtes, ber allgemeinen

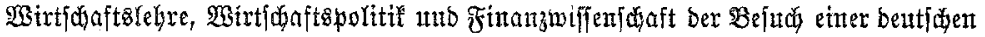

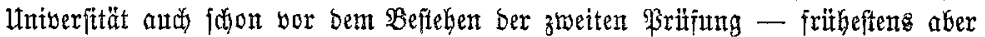

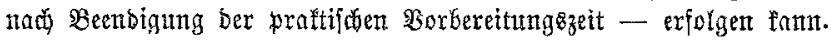

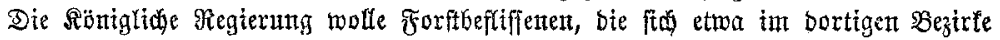

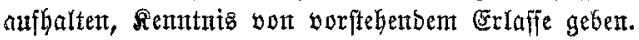

Frbr. o. Squrlemer.

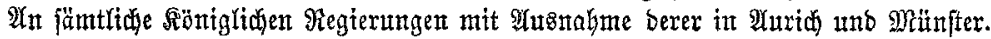

\section{Aneingen.}

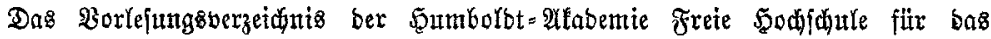

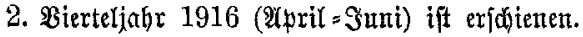

